\title{
Penerapan Metode Blocked Practice Dan Media Footwork Berbasis Teknologi Dalam Upaya Meningkatkan Keterampilan Bermain Bulutangkis
}

\author{
Lalu Sapta Wijaya Kusuma \\ UNDIKMA Mataram \\ lalusaptawk@ikipmataram.ac.id
}

\begin{abstract}
Abstrak
Penelitian tindakan kelas ini didasarkan pada asumsi bahwa permasalahan dan kesulitan belajar yang terjadi di dalam kelas bisa dipecahkan dengan pendekatan dan media pembelajaran yang tepat. Kesulitan proses belajar mengajar dalam mata pelajaran pendidikan jasmani dan olahraga terkait materi bulutangkis yaitu footwork dan lob merupakan sebagai landasan dasar peneliti menggunakan pendekatan yang sesuai dengan karakteristik dari anak sekolah kelas IX di MTs. Mujahidin NW Jempong yaitu pendekatan blocked practice dan media alat footwork. Tujuan dari penelitian ini adalah menawarkan pemecahan pembelajaran gerak dasar footwork dan lob dengan menerapkan pendekatan metode blocked practice dan media alat footwork untuk memberikan kesetaraan gerak antara siswa secara keseluruhan. Desain penelitian yang digunakan adalah mengacu pada model spiral sebagai salah satu model penelitian tindakan kelas, dengan alur dari mulai tahap perencanaan, tindakan, observasi, dan refleksi. Sedangkan untuk memperoleh data menggunakan tes pengetahuan/kognitif, observasi/afektif, dan unjuk kerja/psikomotor. Setelah data didapatkan dan di analisis melalui 4 tahapan berdasarkan kriteria yang sudah ditetapkan, maka hasil yang diperoleh selama 2 siklus pembelajaran adalah siklus pertama 14 siswa memenuhi KKM dan 7 siswa tidak memenuhi KKM. Sedangkan pada siklus kedua dari total 21 siswa semuanya memenuhi KKM yang sudah ditetapkan tentang penelitian tindakan kelas yaitu $\geq 78$ memenuhi KKM dan $\leq 78$ tidak memenuhi KKM. Berdasarkan patokan tersebut maka pada siklus kedua 21 siswa memenuhi KKM berdasarkan tiga domain yang diujikan yaitu kognitif, efektif, dan psikomotor dengan ratarata 82.1 Sehingga kesimpulannya siklus selanjutnya tidak perlu dilanjutkan. Sehingga penerapan metode blocked practice dan media alat footwork berbasis teknologi dapat diterapkan untuk meningkatkan kemampuan footwork dan lob dalam permainan bulutangkis.
\end{abstract}

Kata Kunci: Blocked Practice, Footwork Berbasis Teknologi, Keterampilan Bermain Bulutangkis.

\begin{abstract}
This classroom action research is based on the assumption that learning problems and difficulties that occur in the classroom can be solved with the right approach and learning media. Difficulties in the teaching and learning process in physical education and sports subjects related to badminton material namely footwork and lob are the basic foundation of the researcher to use an approach that is in accordance with the characteristics of grade IX school children in MTs. Mujahidin NW Jempong is a blocked practice approach and media footwork tool. The purpose of this study is to offer a solution to the basic motion learning footwork and lob by applying the approach of the blocked practice method and the media footwork tool to provide equality of motion between students as a whole. The research design used is referring to the spiral model as one of the classroom action research models, with a flow from the planning, action, observation, and reflection stages. Meanwhile, to obtain data using knowledge/cognitive tests, observation/affective, and performance/psychomotor. After the data is obtained and analyzed through 4 stages based on established criteria, the results obtained during the 2 learning cycles are the first cycle of 14 students fulfilling the KKM and 7 students not fulfilling the KKM. Whereas in the second cycle out of a total of 21 students all met the KKM that had been set about classroom action research that was $\geq 78$ fulfilling the KKM and $\leq 78$ did not meet the KKM. Based on these benchmarks, in the second cycle 21 students met the KKM based on three domains tested namely cognitive, effective, and
\end{abstract}


psychomotor with an average of 82.1 So that the conclusion the next cycle did not need to be continued. So the application of blocked practice methods and technology-based footwork media tools can be applied to improve the ability of footwork and lob in badminton games.

\section{Keyword: Blocked Practice, Technology-Based Footwork, Badminton Playing Skills}

\section{PENDAHULUAN}

Permainan bulutangkis merupakan salah satu permainan yang mengandal keterampilan tingkat tinggi, baik teknik, fisik, dan mental. Sehingga tidak jarang atlet dunia berlatih dari tingkat usia dini sampai remaja untuk mendapatkan keterampilan level tingkat tinggi. Beberapa keterampilan teknik dasar yang harus dimiliki oleh seorang pemain bulutangkis yaitu; footwork, servis, smash, dropshoot, drive, lob, netting, dan return smash.

Semua keterampilan diatas mutlak dibutuhkan oleh seorang pemain untuk menjadi pemain top dunia. Keterampilan tersebut tidak bisa dilatih dalam waktu yang singkat melainkan dibutuhkan proses latihan yang cukup lama dari masing-masing pemain, ada yang berlatih hingga 10 sampai 12 tahun untuk mendapatkan keterampilan tersebut. Tentunya hal tersebut dipengaruhi factor internal dan ekternal pemain, yaitu: factor internal; kondisi fisik (fisiologis), mental pemain (psikologis), dan kecerdasan kinestetik pemain. Sedangkan factor eksternal berupa; pendekatan latihan, lingkungan social siswa yang meliputi; keluarga, masyarakat, dan lingkungan sekolah. Di lingkungan sekolah tentunya terkait dengan proses belajar mengajar.

Oleh karena itu sebisa mungkin proses belajar mengajar menyesuaikan dengan kemampuan dan kematangan siswa dalam menerima setiap materi pembelajaran. Guru harus bisa menentukan pendekatan yang tepat dalam meningkatkan prestasi belajar siswa, terutama pada mata pelajaran permainan bulutangkis. Hal tersebut diperkuat dengan Undang-Undang Republik Indonesia Nomor 2 Tahun 2005 Pasal 25 butir 2 berbunyi "Pembinaan dan pengembangan olahraga pendidikan dilaksanakan melalui proses pembelajaran yang dilakukan guru dan dosen olahraga yang berkualifikasi dan memiliki sertifikat kompetensi serta didukung prasarana dan sarana olahraga yang memadai".

Pada penugasan dosen di sekolah (PDS) pelaksanaan pembelajaran di MTs. Mujahidin NW Jempong pada materi pembelajaran bulutangkis, peneliti menemukan beberapa permasalahan yang terjadi, diantaranya adalah: (1) siswa sulit melakukan teknik olah kaki (footwork) dengan baik, (2) siswa masih belum mampu melakukan teknik lob (pukulan lambung).

Ketiga keterampilan tersebut merupakan teknik yang paling dasar yang harus dimiliki oleh seorang siswa, baik tidaknya keterampilan tersebut akan menentukan kemampuan siswa di lapangan permainan. Menurut beberapa ahli pendekatan merupakan salah satu faktor penentu siswa bisa melakukan berbagai keterampilan yang diajarkan, seperti pendapat (Trianto, 2009) yang menyatakan berbagai metode pembelajaran telah digunakan peneliti sekaligus guru bidang studi penjasorkes dalam menyampaikan materi pembelajaran. Metode tersebut diantaranya adalah metode komando, resiprokal, kooperatif, dan lain sebagainya.

Olahraga yang merupakan pembelajaran yang berbasis gerak, maka gerak tidak bisa dilatih dalam satu kali tatap muka, melainkan harus terus-menerus dan berkelanjutan, dan atau berulang-ulang untuk beralih ke tahap keterampilan yang lain. Salah satu metode yang dilakukan secara terus menerus dan berulang-ulang adalah Metode blocked practice. Dimana metode tersebut menurut Samsudin (2008) "Metode blocked practice (metode latihan terpusat) adalah cara yang digunakan guru untuk mengajarkan dua atau tiga keterampilan yang dilatih dilaksanakan satu per satu hingga jumlah atau waktu yang ditentukan terselesaikan, sebelum dilanjutkan ke keterampilan lain”. 


\section{Metode Blocked Practice}

Pendekatan dapat diartikan sebagai titik tolak atau sudut pandang kita terhadap proses pembelajaran. Istilah pendekatan merujuk kepada pandangan tentang terjadinya suatu proses yang sifatnya masih sangat umum. Roy Kellen (1998) mencatat bahwa terdapat dua pendekatan dalam pembelajaran, yaitu pendekatan yang berpusat pada guru (teacher centered aproaches) dan pendekatan yang berpusat pada siswa (student centered approaches). Pendekatan yang berpusat pada guru menurunkan strategi pembelajaran langsung (direct intrukstion), pembelajaran deduktif atau atau ekspositori. Sedangkan pembelajaran yang berpusat pada siswa menurunkan strategi inkuiri dan diskoveri serta pembelajaran induktif (Rusman, 2016).

Penggunaan teknologi merupakan keharusan pada revolusi industry 4.0 sehingga guru dituntut menggunakan alat bantu yang bersifat mutakhir dalam setiap proses belajar mengajar untuk mendapatkan perhatian dan tantangan baru bagi peserta didik. Penggunaan alat bantu melalui teknologi ini dimaksudkan untuk meningkatkan kemampuan teknik dasar bulutangkis peserta didik, dikarenakan konsep dasar penggunaan alat tersebut adalah untuk meningkatkan kemampuan olah kaki dan keterampilan lainnya dalam satu kali tatap muka, dikarenakan pengulangan dari setiap gerakan memungkinkan terjadi setiap saat. Contohnya adalah ketika peserta didik melakukan pukulan netting, hal tersebut dilakukan berdasarkan sinyal arah lampu yang dipasang di depan net dan bukan dari intruksi pelatih melainkan gerakan yang dilakukan oleh peserta didik mengikuti arah lampu yang menyala.

Metode blocked practice digunakan untuk memberikan kesempatan pada siswa agar kemampuan yang diajarkan cepat dikuasai. Metode blocked practice memungkinkan siswa mempunyai pengalaman belajar dalam satu kali tatap muka untuk bisa mengetahui gerakan yang dilakukan sudah baik dan benar, karena proses keterampilan yang diajarkan harus betul-betul dikuasai sebelum berpindah ke keterampilan yang lain. Metode blocked practice hampir memiliki kemiripan dengan metode drill, tetapi metode drill tidak mengharuskan siswa bisa dalam beberapa pengulangan dari satu teknik yang diajarkan melainkan penekanannya hanya pada pengulangan satu atau dua teknik sekaligus. Sedangkan metode blocked practice mengharuskan siswa harus mampu melakukan salah satu teknik sebelum berpindah ke teknik lainnya.

Ha tersebut di atas sejalan dengan pendapat (Edward, 2011) Block practice adalah sebuah metode latihan dimana berkonsentrasi pada satu aspek keterampilan saja dan dilakukan berulang-ulang dalam waktu yang sudah ditentukan atau sampai atlet menguasai aspek teknik tersebut sebelum beralih ke aspek teknik yang lain. Kelebihan metode block practice terletak pada kinerja yang bersifat repetitive yang membuat peserta didik untuk mengoreksi dan menyesuaikan diri pada aspek keterampilan yang sedang diajarkan.

\section{Media Footwork Berbasis Teknologi}

Menurut Gagne dan Briggs (dalam Dwiyogo, 2008) berpendapat bahwa media pembelajaran adalah alat secara fisik untuk menyampaikan isi pembelajaran, misalnya buku, tape recorder, kaset, film, video, slide televise, dan lain-lain. Sedangkan Dwiyogo (2008) media pembelajaran adalah bahan/alat, maupn metode/teknik yang digunakan dalam kegiatan belajar-mengaja, dengan maksud agar proses interaksi komunikasi antara gur anak didik/warga belajar dapat berlangusng secara tepatguna dan berdayaguna.

Alat yang digunakan merupakan pengembangan dari footwork konvensioanl yang menempatkan bola (shuttlecock) di sudut lapangan untuk diambil oleh pemain ditempatkan ke sudut lapangan permainan lainnya. Sedangkan media footwork yang digunakan dalam penelitian ini merupakan berbentuk sinyal lampu yang berjumlah 8 sinyal lampu, dimana sinyal lampu menandakan gerakan yang harus dilakukan oleh peserta didik. Jika lampu depan kanan menyala, maka peserta didik harus bergerak 
ke depan kanan seolah-olah mengambil bola netting atau return smash.

Adapun bentuk alat yang dimaksudkan, baik letak, dan kegunaannya dapat dilihat pada gambar 1.1 dibawah ini.

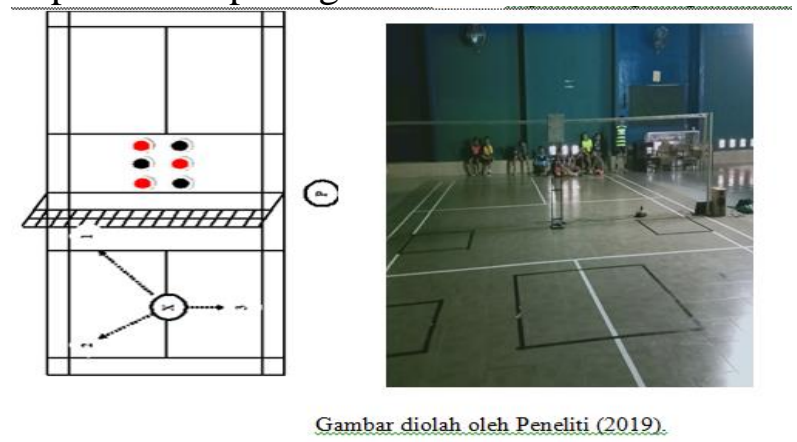

Gambar diolah oleh Peneliti (2019).

\section{Keterangan:}

$\mathrm{X}$ : siswa (pemain) yang

melakukan gerakan footwork

$\mathrm{P} \quad$ : peneliti yang menekan alat sinyal gerak

: alat footwork yang menyala (arah sinyal gerak siswa).

$\rightarrow 132$ : arah gerakan siswa (pemain).

Gambar penempatan lampu isyarat sebagai simulasi arah gerakan bisa dilihat pada gambar dibawah ini:

\section{Pelaksanaan:}

1. Pemain berdiri di tengah lapangan dengan sikap siap melakukan gerakan

2. Pemain melakukan gerakan ketika lampu sinyal menyaladan sekaligus menandai arah gerakan yang harus dilakukan oleh testee

3. Setiap pemain melakukan satu kali gerakan harus kembali ke tengah lapangan permainan (tanda ' $\mathrm{X}$ ' pada lapangan)

4. Lampu 1 menyala testee harus bergerak ke depan sudut kiri permainan (pukulan netting ataupun return)

5. Lampu 2 menyala pemain bergerak ke belakang sudut kiri permainan

6. Lampu 3 menyala testee bergerak ke samping kanan permainan, dan

7. Seterusnya berlanjut sampai ke 6 (enam) atau semua lampu menyala menandai berakhirnya gerakan.

\section{METODE PENELITIAN}

Jenis Penelitian

Setiap jenis penelitian memiliki karakteristik yang berbeda, oleh karena itu dalam penelitian pemilihan jenis penelitian sebagai upaya memecahkan permasalahan yang ada dengan alur yang jelas. Menurut Kristiyanto (2010) penelitian tindakan kelas (classroom action research) merupakan sebuah prosedur metologis yang sebenarnya bukan sama sekali baru, PTK bukanlah "barang baru". PTK telah banyak dipraktikkan sebagai sebuah langkah sistematis untuk memecahkan masalah yang berkaitan dengan persoalan pembelajaran pendidikan jasmani di kelas.

\section{Lokasi dan Tempat Penelitian}

Penelitian ini dilaksanakan di MTs. Mujahidin NW Jempong kelas IX $^{\mathrm{A}}$ yang berjumlah 21 siswa, dengan rincian 8 orang siswa laki-laki dan 13 perempuan. Penugasan dosen di sekolah (PDS) terlaksana dari bulan Agustus sampai dengan September 2019 sebagai bagian dari proyek ristekdikti kepada IKIP Mataram dengan menugaskan dosen dari masing-masing prodi yang ada di lingkungan IKIP Mataram, salah satunya adalah prodi pendidikan jasmani dan olahraga sebagai bagian Tim PDS.

\section{Instrumen Penelitian}

Dalam penelitian ini instrumen atau alat ukur yang digunakan adalah lembar penilian afektif, lembar penilaian psikomotorik, dan lembar penilaian kognitif.

Penilaian afektif digunakan untuk mengukur perilaku siswa ketika pembelajaran berlangsung, untuk penilaian psikomotor dimaksudkan untuk menggambarkan penguasaan prosedur gerak dan koordinasi, dan penilaian kognitif untuk mengukur intelektual siswa. Lembar penilaian kognitif berisi mengenai materi pokok bahasan bulutangkis dengan bentuk pilihan ganda yaitu skor 1 (Ya) dan skor 0 (Tidak).

Adapun kisi-kisi instrumen yang digunakan dalam penelitian ini dapat dilihat pada tabel 1 dibawah ini: 
Tabel 1 Domain Insrumen Penelitian Dikjasor

\begin{tabular}{|c|c|c|}
\hline \multicolumn{3}{|c|}{ DOMAIN INTRUMEN PENELITIAN } \\
\hline Kognitif & Afektif & Psikomotor \\
\hline $\begin{array}{l}\text { Memahami teknik dasar } \\
\text { permainan bulutangkis: } \\
\text { a. Footwork } \\
\text { b. Lob }\end{array}$ & $\begin{array}{ll}\text { a. } & \text { Disiplin } \\
\text { b. } & \text { Kerjasama } \\
\text { c. Semangat } \\
\text { d. Saling } \\
& \text { Menghormati }\end{array}$ & $\begin{array}{l}\text { Mengusai teknik } \\
\text { dasar bulutangkis: } \\
\text { a. Footwork } \\
\text { a. Lob }\end{array}$ \\
\hline
\end{tabular}

\section{Tehnik Analisa Data}

Adapun tehnik yang digunakan dalam mengumpulkan data penelitian adalah dengan menggunakan metode tes, observasi, dan metode unjuk kerja. Metode tes digunakan untuk mengetahui pemahaman peserta didik terkait dengan materi pembelajaran bulutangkis yaitu; footwork, serves, dan lob. Sedangkan teknik observasi digunakan untuk mengetahui sejauhmana sikap peserta didik ketika pembelajaran berlangsung. Unjuk kerja digunakan untuk mengetahui sejauhmana tingakat penguasaan teknik yang sudah diajarkan oleh guru terkait dengan materi bulutangkis yang sudah diajarkan, mengenai; footwork, serves, dan lob.

Data hasil penelitian di analisis dengan menggunakan teknik dibawah ini:

1. Untuk menentukan nilai akhir hasil belajar yang diperoleh masing-masing siswa, digunakan rumus:

$$
\text { Nilai }=\frac{\sum \text { jumlah } \text { jawaban } \text { yang benar }}{\sum \text { jumlah seluruh soal }} \times 100
$$

1. Menentukan nilai rata-rata kelas, yaitu:

$$
\text { Nilai }=\frac{\sum \text { nilai semua siswa }}{\sum \text { siswa }} \times 100
$$

2. Untuk menentukan tingkat tuntas belajar klasikal, yaitu:

Nilai

$\frac{\sum \text { siswa yang memenuhi nilai } K K M}{\sum \text { siswa yang mengikuti tes }} \times 100$

3. Untuk menentukan nilai hasil observasi yang meliputi penilaian afektif dan penilaian psikomotorik, digunakan rumus:

$$
\text { Nilai }=\frac{\sum \text { skor yang diperoleh }}{\sum \text { skor maksimal }} \times 100
$$

Sumber: Arikunto (2006) Prosedur Penelitian Suatu Pendekatan Praktik.

\section{Indikator Keberhasilan Belajar}

Norma keberhasilan pembelajaran bertujuan untuk mengetahui sejauhmana masing-masing domain sudah berhasil atau tidak meningkatkan obyek yang diteliti. Adapun norma keberhasilan pembelajaran yang dimaksud bisa dilihat pada tabel 2 di bawah ini:

\section{Tabel 2 Indikator Keberhasilan Belajar}

\begin{tabular}{|c|c|c|}
$\begin{array}{c}\text { Pencapaian Tujuan } \\
\text { Pembelajaran }\end{array}$ & Kualifikasi & $\begin{array}{c}\text { Tingkat } \\
\text { Keberhasilan } \\
\text { Pembelajaran }\end{array}$ \\
\hline $85-100 \%$ & Sangat Baik & Berhasil \\
\hline $65-84 \%$ & Baik & Berhasil \\
\hline $55-64 \%$ & Cukup & Tidak Berhasil \\
\hline $0-54 \%$ & Kurang & Tidak Berhasil \\
\hline
\end{tabular}

Tabel 3 dibawah ini merupakan kriteria ketuntasan minimal (KKM) dengan patokan norma adalah:

Tabel 3 Kriteria Ketuntasan Minimal (KKM)

\begin{tabular}{|c|c|}
\hline Kriteria Ketuntasan & Kualifikasi \\
\hline$\geq 78$ & Tuntas \\
\hline$\leq 78$ & Tidak Tuntas \\
\hline
\end{tabular}

Sumber: Zainal Aqib (2011) Penelitian Tindakan Kelas.

HASIL PENELITIAN DAN

\section{PEMBAHASAN}

\section{Tes Kognitif Siklus I}

Pada siklus I hasil belajar kognitif siswa mempunyai rata-rata sebesar 78,6 pada siklus I dengan rincian 2 orang siswa kriteria sangat baik dan 19 siswa criteria baik. Ratarata soal nomor satu Sebanyak $71.4 \%$, soal nomor dua sebanyak $85.7 \%$, soal nomor tiga sebanyak $71.4 \%$, soal nomor empat sebanyak $76.2 \%$, soal nomor lima sebanyak $66.7 \%$, soal nomor enam sebanyak $81 \%$, soal nomor tujuh sebanyak $85.7 \%$, dan soal nomor delapan sebanyak $90.5 \%$, soal nomor sembilan sebanyak $81 \%$, dan soal nomor 10 sebanyak $76.2 \%$, sehingga jumlah rata-rata pemahaman siswa terhadap pembelajaran bulutangkis melalui tes tulis yang diberikan adalah sebesar 78.6 (baik). Untuk lebih jelas dapat dilihat pada tabel dibawah ini:Tabel 4 hasil belajar kognitif pada siklus I

\begin{tabular}{|c|c|c|c|}
\hline No. & Keterangan & Jumlah Siswa & Persentase \\
\hline 1 & Sangat baik & 2 & $10 \%$ \\
\hline 2 & Baik & 19 & $90 \%$ \\
\hline 3 & Cukup & - & - \\
\hline 4 & Kurang & & \\
\hline
\end{tabular}

\section{Observasi Afektif Siklus I}

Hasil observasi pada lembar afektif dengan menggunakan pendekatan blocked practice dan media alat footwork pembelajaran bulutangkis pada siklus I dapat 
dilihat pada tabel berikut ini:Tabel 5 hasil belajar afektif pada siklus I

\begin{tabular}{|c|c|c|c|}
\hline No. & Keterangan & $\begin{array}{c}\text { Jumlah } \\
\text { Siswa }\end{array}$ & Persentase \\
\hline 1 & Sangat baik & - & - \\
\hline 2 & Baik & 21 & $100 \%$ \\
\hline 3 & Cukup & - & - \\
\hline 4 & Kurang & - & - \\
\hline
\end{tabular}

Persentase nilai rata-rata siswa untuk ranah afeksi selama pembelajaran pada siklus I berlangsung, menunjukkan nilai disiplin siswa sebesar $76.2 \%$, kerjasama $71.4 \%$, semangat $77.1 \%$, menghormati teman $82.9 \%$. Sehingga rata-rata sikap siswa setelah siklus I (satu) dilaksanakan dengan persentase sebesar 78.1 (baik).

\section{Tes Psikomotor Siklus I}

Hasil belajar unjuk kerja pada domain psikomotor dengan pendekatan metode blocked praktice dan pemanfaatan alat footwork berbasis teknologi dapat dilihat pada tabel dibawah ini:

Tabel 6 hasil belajar Psikomotor pada siklus I

\begin{tabular}{|c|c|c|c|}
\hline No. & Keterangan & $\begin{array}{c}\text { Jumlah } \\
\text { Siswa }\end{array}$ & Persentase \\
\hline 1 & Sangat baik & - & - \\
\hline 2 & Baik & 21 & $100 \%$ \\
\hline 3 & Cukup & - & - \\
\hline 4 & Kurang & & - \\
\hline
\end{tabular}

Persentase nilai rata-rata siswa untuk ranah psikomotor selama proses belajar pada siklus I berlangsung, menunjukkan nilai pada saat melakukan footwork dan lob: (1) footwork; Gerakan kaki dan tangan seirama ketika maju kaki dominan lebih dulu bergerak dengan persentase sebesar $76 \%$, sedangkan untuk gerakan kaki dan tangan seirama ketika mundur kaki dominan lebih dalu bergerak $77 \%$. (2) lob; Impact bola pada saat melakukan pukulan lob berada di atas kepala dengan persentase sebesar $78 \%$, sedangkan untuk gerakan jatuhnya bola harus di belakang garis base line lawan $82 \%$. Sehingga rata-rata unjuk kerja psikomotor siswa persentasenya sebesar 78.3 (baik).

Rakapitulasi hasil dari siklus I untuk ketiga domain yaitu; kognitif, afektif, dan psikomotor dapat dilihat pada tabel dibawah ini;
Tabel 7 rekapitulasi penilaian ketiga domain

\begin{tabular}{|l|c|c|}
\hline \multirow{2}{*}{ Domain penilaian } & \multicolumn{2}{|c|}{ Siklus I } \\
\cline { 2 - 3 } & Rata-rata & Keterangan \\
\hline Kognitif & 78.6 & Baik \\
\hline Afektif & 78.1 & Baik \\
\hline Psikomotor & 78.3 & Baik \\
\hline K Nilai Akhir & \multicolumn{2}{|c|}{$\mathbf{7 8 . 3}$ (Baik) } \\
\hline
\end{tabular}

Tabel 8 ketuntasan hasil belajar siklus I

\begin{tabular}{|l|l|c|c|}
\hline No. & Keterangan & Jumlah & Persentase \\
\hline & Tuntas & 14 & $66.7 \%$ \\
\hline & Tidak & 7 & $33.3 \%$ \\
& Tuntas & & \\
\hline
\end{tabular}

Untuk nilai akhir hasil belajar secara keseluruhan pada siklus I diperoleh nilai ratarata sebesar 77.2. Dengan rincian 14 siswa tuntas atau dengan persentase ketuntasan klasikal sebesar $66.7 \%$. Sedangkan siswa yang tidak tuntas persentasenya sebesar $33.3 \%$ dengan jumlah siswa 7 orang.

\section{Tes Kognitif Siklus II}

Untuk menilai hasil belajar kognitif siswa digunakan lembar tes yang sama pada siklus I. Hasil belajar kognitif siswa pada siklus II ini memperoleh nilai ratarata yaitu 83.8. Pada siklus II yang memperoleh nilai kognitif sangat baik adalah 8 siswa (38.1\%), kategori baik dengan jumlah 13 siswa (baik), kategori cukup dan kurang tidak ada. Berikut rincian persentase jawaban siswa dari tes yang diberikan: soal nomor satu dengan persentase jawaban sebesar $76.2 \%$, soa nomor dua dengan persentase jawaban sebesar $90.5 \%$, soal nomor tiga sebesar $76.2 \%$, soal nomor empat sebesar $81 \%$, soal nomor lima sebesar $81 \%$, soal nomor enam sebesar $85.7 \%$, soal nomor tujuh sebesar $85.7 \%$, soal nomor delapan $90.5 \%$, soal nomor Sembilan $85.7 \%$, dan soal nomor sepuluh $85.7 \%$. Jumlah rata-rata pemahaman siswa terhada materi bulutangkis melalui metode blocked practice dan media alat footwork sebesar 83.8 (baik).

Untuk lebih jelasnya rincian persentase pada siklus II meningkat dengan 9 siswa kategori sangat baik (SB) dan kategori baik (B) 12 siswa, bisa dilihat pada tabel dibawah ini. 
Tabel 9 data kognitif siklus II

\begin{tabular}{|c|c|c|c|}
\hline No. & Keterangan & $\begin{array}{c}\text { Jumlah } \\
\text { Siswa }\end{array}$ & Persentase \\
\hline 1 & Sangat baik & 8 & $38.1 \%$ \\
\hline 2 & Baik & 13 & $61.9 \%$ \\
\hline 3 & Cukup & - & - \\
\hline 4 & Kurang & & - \\
\hline
\end{tabular}

\section{Observasi Afektif Siklus II}

Persentase nilai rata-rata siswa untuk ranah afeksi selama setelah pembelajaran pada siklus II berlangsung, menunjukkan nilai disiplin siswa sebesar $79 \%$, kerjasama $82.9 \%$, semangat $79 \%$, menghormati teman $84.8 \%$. Sehingga ratarata sikap siswa setelah siklus I (satu) dilaksanakan dengan persentase sebesar 81.4 (baik).

Tabel 10 data Efektif siklus II

\begin{tabular}{|c|c|c|c|}
\hline No. & Keterangan & $\begin{array}{c}\text { Jumlah } \\
\text { Siswa }\end{array}$ & Persentase \\
\hline 1 & Sangat baik & 9 & $42.86 \%$ \\
\hline 2 & Baik & 12 & $57.14 \%$ \\
\hline 3 & Cukup & - & - \\
\hline 4 & Kurang & & - \\
\hline
\end{tabular}

\section{Tes Psikomotor Siklus II}

Persentase nilai rata-rata siswa untuk ranah psikomotor selama proses belajar pada siklus II berlangsung, menunjukkan nilai pada saat melakukan footwork dan lob: (1) footwork; Gerakan kaki dan tangan seirama ketika maju kaki dominan lebih dulu bergerak dengan persentase sebesar $77 \%$, sedangkan untuk gerakan kaki dan tangan seirama ketika mundur kaki dominan lebih dulu bergerak $79 \%$. (2) lob; Impact bola pada saat melakukan pukulan lob berada di atas kepala dengan persentase sebesar $79 \%$, sedangkan untuk gerakan jatuhnya bola harus di belakang garis base line lawan $87 \%$. Sehingga ata-rata unjuk kerja psikomotor siswa persentasenya sebesar 81 (baik).

Tabel 11 data tes psikomotor siklus II

\begin{tabular}{|c|c|c|c|}
\hline No. & Keterangan & $\begin{array}{c}\text { Jumlah } \\
\text { Siswa }\end{array}$ & $\begin{array}{c}\text { Persent } \\
\text { ase }\end{array}$ \\
\hline 1 & Sangat baik & 8 & $38.10 \%$ \\
\hline 2 & Baik & 13 & $61.90 \%$ \\
\hline 3 & Cukup & - & - \\
\hline 4 & Kurang & & - \\
\hline
\end{tabular}

Jurnal Ilmu Sosial dan Pendidikan
Rakapitulasi hasil dari siklus II untuk ketiga domain yaitu; kognitif, afektif, dan psikomotor dapat dilihat pada tabel dibawah ini:

Tabel 12 rekapitulasi penilaian ketiga domain Siklus II

\begin{tabular}{|l|c|c|}
\hline \multirow{2}{*}{$\begin{array}{c}\text { Domain } \\
\text { Penilaian }\end{array}$} & \multicolumn{2}{|c|}{ Siklus II } \\
\cline { 2 - 3 } Kognitif & Rata-rata & Keterangan \\
\hline Afektif & 83.8 & Baik \\
\hline Psikomotor & 81.4 & Baik \\
\hline $\begin{array}{c}\text { E Nilai } \\
\text { Akhir }\end{array}$ & \multicolumn{2}{|c|}{ 82.1 (Baik) } \\
\hline
\end{tabular}

Tabel 13 ketuntasan klasikal Siklus II

\begin{tabular}{|c|l|c|c|}
\hline No. & Keterangan & Jumlah & Persentase \\
\hline 1. & Tuntas & 21 & $100 \%$ \\
\hline 2. & Tidak Tuntas & - & - \\
\hline
\end{tabular}

Untuk nilai akhir hasil belajar secara keseluruhan pada siklus II diperoleh nilai rata-rata sebesar 82.1 kategori (baik) dari 21 siswa semua tuntas dengan ketuntasan sebesar $100 \%$. Ketuntasan tersebut memiliki peningkatan sangat signifikan melalui penerapan metode blocked practice dan media alat footwork dalam meningkatkan kemampuan olah kaki (footwork) dan pukulan lambung (lob).

\section{PEMBAHASAN}

Pelaksanaan siklus I menunjukkan adanya peningkatan hasil belajar siswa dari pembelajaran yang sebelumnya, penerapan metode blocked practice dan media alat footwork cukup signifikan meningkatkan hasil belajar siswa terhadap mata pelajaran bulutangkis, khsusunya materi footwork (olah kaki) dan lob (pukulan lambung). Dengan adanya penerapan metode blocked practice dan media alat footwork mengangkat motivasi siswa dalam melakukan setiap gerakan yang di contohkan atau akan diperagakan oleh siswa sendiri.

Metode bloked practice memberikan siswa kesempatan untuk bisa secara bersamasama sebelum melakukan gerakan lain, sehingga hal tersebut tidak terjadi kesenjangan gerakan antara siswa yang satu dengan siswa yang lainnya. Sejalan dengan 
pendapat (Mulyanto, n.d.) bahwa untuk menguasai suatu keterampilan gerak perlu dilakukan dalam latihan secara kontinyu sebagai proses perubahan dari fase ShortTerm Memory (STM) menuju pada fase LongTerm Memory (LTM). Sehingga menjadi keterampilan yang menetap, seperti pada saat belajar mengendarai sepeda dan belajar berenang. Sedangkan menurut Pratama \& Syahudi (2016) dalam penelitiannya menyatakan bahwa metode block practice memiliki pengaruh terbaik diantara ketiga metode tersebut (serial practice dan random practice). Hal ini dikarenakan block practice memiliki tingkat konstektual rendah, hal ini dikarenakan pada block practice peserta didik atau atlet dapat beradaptasi pada jarak yang telah ditentukan, seperti yang diungkapkan Edwards (2011) bahwa dengan kerja yang bersifat repetitive memungkinkan peserta didik untuk mencari dan menyesuaikan fokus dan perhatian pada isyarat lingkungan yang tepat, mencapai dan mempertahankan tingkat gairah yang tepat, dan dapat meningkatkan tingkat motivasi karena peningkatan kadar kesuksesan melakukan satu gerakan atau keterampilan.

Menurut (Nugraha, 2015) menyatakan model produk pengembangan sinyal lampu 3 warna untuk alat bantu kelincahan footwork ini dapat digunakan untuk fun game exercise, supaya selama latihan tidak jenuh dan untuk atlet yang baru masuk klub, tentunya akan menjadi pengalaman baru bermain dengan pengembangan sinyal lampu 3 warna untuk alat bantu kelincahan footwork yang didesain untuk prestasi atlet. Begitu juga dengan penerapan media alat footwork membuat siswa termotivasi melakukan gerakan tersebut dari pada guru hanya menempatkan bola disetiap sudut lapangan atau maju mundur sesuai intruksi dari guru. Tetapi dengan menggunakan alat footwork siswa akan bergerak sesuai sinyal lampu yang menyala pada alat footwork, hal tersebut menjadi tantangan bagi siswa yang belum pernah melihat dan merasakan gerakan yang diperintahkan berdasarkan stimulus dari luar atau obyek tertentu sehingga meningkatkan kemampuan perseptual siswa dalam mengolah informasi dari luar.

Penggunaan media alat footwork ini menjadi pengalaman belajar baru bagi siswa khsususnya di MTs NW Mujahiddin Jempong tempat Penugasan Dosen di Sekolah (PDS). Penggunaan alat footwork yang dirancang oleh guru sebagai bagian dari inovasi pembelajaran pada tingkatan keterampilan yang paling dasar pada olahraga bulutangkis yaitu footwork dan lob dapat memudahkan siswa untuk bisa beradaptasi sesuai dengan keadaan permainan sebenarnya pada olahraga bulutangkis saat media atau alat tersebut digunakan sebagai bagian dari proses belajar mengajar.

Penerapan metode blocked practice dan media alat footwork pada mata pelajaran bulutangkis meningkatkan kemampuan siswa dalam melakukan setiap gerakan secara baik dan benar.

\section{SIMPULAN}

Berdasarkan hasil penelitian yang diperoleh melalui 2 siklus, dimana pada siklus pertama 14 siswa memenuhi KKM dan 7 siswa tidak memenuhi KKM (kriteria ketuntasan minimal). Sedangkan pada siklus kedua dari total 21 siswa semuanya memenuhi KKM yang sudah ditetapkan berdaarkan acuan dari (Aqib, 2011) tentang penelitian tindakan kelas yaitu $\geq 78$ memenuhi KKM dan $\leq 78$ tidak memenuhi KKM. Berdasarkan patokan tersebut maka pada siklus kedua 21 siswa memenuhi KKM berdasarkan tiga domain yang diujikan yaitu kognitif, efektif, dan psikomotor dengan ratarata 82.1 sehingga kesimpulannya siklus selanjutnya tidak perlu dilanjutkan. Sehingga kesimpulannya siklus selanjutnya tidak perlu dilanjutkan. Sehingga penerapan metode blocked practice dan media alat footwork berbasis teknologi dapat diterapkan untuk meningkatkan kemampuan footwork dan lob dalam permainan bulutangkis.

\section{SARAN}

Berdasarkan hasil temuan yang diperoleh dalam penelitian melalui pembelajaran bulutangkis dengan pendekatan blocked practice dan media alat footwork, bahwa: 
1. Siswa dalam melakukan proses gerak butuh waktu yang cukup lama dalam menguasai satu jenis gerakan, sehingga pendekatan yang baik akan menentukan peningkatan kemampuan siswa dalam menerima serta mempraktikkan gerakan yang diajarkan.

2. Pendekatan dan media alat tertentu akan merangsang dan memotivasi siswa untuk berani bergerak dan belajar melalui gerak yang dilakukan.

3. Merangsang kemampuan motorik anak untuk bergerak berdasarkan stimulus dari media pembelajaran dapat meningkatkan kemampuan perseptual siswa sejak dini.

\section{DAFTAR PUSTAKA}

Aqib, Z., (2011). Penelitian Tindakan Kelas.

Bandung: Yrama Widya.

Arikunto, S., (2006). Prosedur Penelitian Suatu Pendekatan Praktik. Jakarta: PT Rineka Cipta.

Dwiyogo, W. D. (2008). Media Pembelajaran Penjas Dan Olahraga. Malang: Universitas Negeri Malang.

Kridiyana, R., (2010). Merangsang Gerak Reaksi Olahragawan Bulutangkis Dengan Menggunakan Bola Lampu. Sumber: https://ratihkrisdiyana.wordpress.com/ 2010/12/15/merangsang-gerak-reaksiolahragawan-bulutangkis-denganmenggunakan-bola-lampu/. (Artikel, posted on Desember 15. 2010). Diakses tanggal 7 Maret 2019.

Kristiyanto, A., (2010). Penelitian Tindakan Kelas Dalam Pendidikan Jasmani Dan Kepelatihan Olahraga. Surakarta: Sebelas Maret University Press.

Maksum, A., (2009). Metodologi Penelitian Dalam Olahraga. Surabaya. Unesa University Press.

Marrozan, (2013). Penerapan Modifikasi Alat Bantu Pembelajaran Bokortasko Terhadap Hasil Belajar Bulutangkis Siswa Kelas VIII d Di SMPN 3 Batang tahun 2012. Pendidikan Jasmani Kesehatan Dan Rekreasi Fakultas Ilmu Keolahragaan Universitas Negeri Semarang.
Mulyanto, R., (n.d.) Managemen Pembelajaran Metode Block Practice Dan Prinsip Dap Terhadap Keterampilan Renang Gaya Dada Siswa Kelas Iii Sekolah Dasar Negeri Neglasari Kecamatan Situraja Kabupaten Sumedang. Universitas Pendidikan Indonesia ISSN 1412-565X.

Muthiarani, A., (2017). Pengaruh Latihan Shadow Menggunakan Langkah Berurutan Dan Langkah Bersilangan Terhadap Kelincahan Footwork Atlet Bulutangkis PB. Wiratama Jaya Yogyakarta. Fakultas ilmu Keolahragaan: Universitas Negeri Yogyakarta.

Nasfiannoor, M. (2009). Pendekatan Statistik Modern Untuk Ilmu Sosial. Jakarta: Salemba Humanika.

Nugraha, F., 2015. Pengembangan Sinyal Lampu 3 Warna Untuk Alat Bantu Kelincahan Footwork Pada Klub Pb.Mandiri Pati Tahun 2015 (Skripsi).

Semarang: Universitas Negeri Semarang.

Nurhasan, (2000). Tes Dan Pengukuran Pendidikan Olahraga. Jakarta: Fakultas Pendidikan Olahraga Dan Kesehatan. Universitas Pendidikan Indonesia.

Pratama, R. \& Syahudi, A. W., (2016). Pengaruh Metode Latihan Block Practice, Serial Practicedan Random Practice Terhadap Peningkatan Akurasi Tembakan Dua Angka Pada Permainan Bola Basket. Proceeding Seminar Nasional Olahraga 2016 Program S3 Pendidikan Olahraga Pascasarjana UNJ ISSN 2549-2780.

Purnama, S. K., (2010). Kepelatihan Bulutangkis Modern. Surakarta: Yuma Pustaka.

Rusman, (2016). Model-model Pembelajaran, Mengembangkan Profesionalitas Guru. Jakarta: PT. Raja Grafindo Persada.

Subarjah. H., (2004). Pendekatan Keterampilan Taktis Dalam

Pembelajaran Bulutangkis. Jakarta: Direktorat Jenderal Olahraga, Depdiknas. 
Sujianto, E. A., (2009). Aplikasi Statistik

Dengan SPSS 16.0. Jakarta: Prestasi

Pustaka. 